\title{
Salinity Effects on Development and Productivity of Crambe (Crambe abyssinica) under Greenhouse Conditions
}

\author{
Ana Carolina F. de Vasconcelos ${ }^{1}$, Lúcia Helena G. Chaves ${ }^{1 *}$, Felipe G. Souza ${ }^{*}$, \\ Hans R. Gheyi ${ }^{*}$, Josely D. Fernandes ${ }^{2}$ \\ ${ }^{1}$ Federal University of Campina Grande, Campina Grande, Brazil \\ ${ }^{2}$ State University of Paraíba, Lagoa Seca, Brazil \\ Email: ana3carol@yahoo.com.br, ${ }^{*}$ Ihgarofalo@hotmail.com, ${ }^{*}$ felipeguedesjm 16@hotmail.com, \\ "hans@agriambi.com.br, joselysolos@yahoo.com.br
}

Received 24 September 2014; accepted 6 April 2015; published 10 April 2015

Copyright (C) 2015 by authors and Scientific Research Publishing Inc.

This work is licensed under the Creative Commons Attribution International License (CC BY).

http://creativecommons.org/licenses/by/4.0/

(c) (i) Open Access

\begin{abstract}
Salinity in soil or water in arid and semi arid regions can severely limit crop production, since the high amount of $\mathrm{NaCl}$ contributes to specific ion effects of $\mathrm{Cl}^{-}$, $\mathrm{Na}^{+}$or both, and to antagonistic effects on nutrient elements. Affected by salt stress, most of the cultivated plants do not fully express their growth potential, which lowers their economic value. Crambe (Crambe abyssinica) is an oil plant of the cruciferous family and it is believed that crambe has great potential to figure as raw material for biofuel; however, literature is not abundant about the effects of salinity in crambe production. This work was carried out in order to evaluate the effects on the development and productivity of crambe irrigated with saline waters under greenhouse conditions. Treatments resulted from the combination of two factors: salinity of irrigation water (ECw) in five levels (1.03control, 2.5, 4.0, 5.5, and 7.0 dS·m $\mathrm{m}^{-1}$ ) and two types of salts $\left(\mathrm{NaCl}\right.$ and $\left.\mathrm{NaCl}+\mathrm{CaCl}_{2}\right)$ with three replications, totaling 30 experimental plots. At the end of the experimental period, soil samples from each plot were collected for chemical and salinity of soil saturation extract analyzes. Salt types did not affect plant parameters. However, the salinity levels presented significant effects on the all plant parameters, decreasing their values with the increase of the salt dose. Salinity levels of the solutions used for irrigation in this study affected the growth of plants and grain yield of crambe. Regarding the type of salts, a higher concentration of $\mathrm{Na}$ was observed for $\mathrm{NaCl}$ solutions at 2.5, 4.0 and $5.5 \mathrm{dS} \cdot \mathrm{m}^{-1}$ salinity levels.
\end{abstract}

\footnotetext{
${ }^{*}$ Corresponding authors.
}

How to cite this paper: de Vasconcelos, A.C.F., Chaves, L.H.G., Souza, F.G., Gheyi, H.R. and Fernandes, J.D. (2015) Salinity Effects on Development and Productivity of Crambe (Crambe abyssinica) under Greenhouse Conditions. American Journal of Plant Sciences, 6, 839-847. http://dx.doi.org/10.4236/ajps.2015.67091 


\section{Keywords}

\section{Crambe, Oil Seed, Salinity Tolerance}

\section{Introduction}

Salinity in soil or water is one of the major stresses and especially in arid and semi arid regions; salinity can severely limit crop production. In many irrigated areas of the world, farmers are forced to use saline water to irrigate their crops due to inadequate supplies of fresh water [1]. Saline water contains high amounts of $\mathrm{NaCl}$, which contribute to specific ion effects of $\mathrm{Cl}^{-}, \mathrm{Na}^{+}$or both, and to antagonistic effects on nutrient elements. Other ions that contribute to soil salinity include $\mathrm{SO}_{4}^{2-}, \mathrm{HCO}_{3}^{-}, \mathrm{Ca}^{2+}, \mathrm{Mg}^{2+}$, and, rarely, $\mathrm{NO}_{3}^{-}$or $\mathrm{K}^{+}$. The salts of these ions occur in highly variable concentrations and proportions. They may be indigenous, but more commonly they are brought into an area in the irrigation water or in waters draining from adjacent areas [2].

Nutrient imbalances may result from the effect of salinity on nutrient availability, uptake, and partitioning within the plant or may be caused by physiological inactivation of a given nutrient, raising the internal requirement of the plant for that essential element. Salinity stress has stimulatory as well as inhibitory effects on the uptake of some macro and micronutrients by plants. The uptake of $\mathrm{Fe}, \mathrm{Mn}, \mathrm{Zn}$, and $\mathrm{Cu}$ generally was increased in crop plants under salinity stress [3].

Affected by salt stress, most of the cultivated plants do not fully express their growth potential, which lowers their economic value. Saline soils contain soluble salts in quantities that affect plant growth adversely. The lower limit for a saline soil has been set conventionally at an electrical conductivity of $4 \mathrm{dS} \cdot \mathrm{m}^{-1}$ in the soil saturation extract. Actually, sensitive plants are affected at half of this salinity, and the highly tolerant ones can resist at about twice this salinity [1].

Crambe (Crambe abyssinica) is an oil plant of the cruciferous family native of the Mediterranean region from Ethiopia to Tanzania for ornamental purposes and with high economical value, especially in Central Asia and the Aral Sea region; however, it is cultivated in tropical and subtropical regions [4]. The literature is not abundant about the effects of salinity in crambe production, although it is believed that crambe has great potential to figure as raw material for biofuel, among the 40 oil species already known with this potential [5]. Crambe is usually used for the production of oil for industrial products, such as industrial lubricant, corrosion inhibitor and as an ingredient in the manufacture of synthetic rubber [6].

Crambe is a low input crop when compared with many other oil crops that can be cultivated. This offers potential to reduce the use and hence environmental burden of fertilizers and water. According to [7], crambe has been chosen as the candidate crop platform for industrial production of wax esters because its oil is not suitable for use in food applications. Moreover, nowadays there is a consensus by all major biotech companies that there is a risk in developing industrial feedstock production in the same crop that is also used for the food market. This is due to the fact that infrastructure in agriculture today does not allow fail-safe separation of different qualities of the same crop.

The industrial oils to be produced in genetically engineered plants are not intended for food use and must therefore not enter the food or feed chain. Crambe naturally contains up to $60 \%$ of erucic acid, a suitable long chain fatty acid for conversion into the fatty alcohols needed in the production of several of the wax ester types, which disqualifies it for food production. Crambe is already a high yielding oil crop, presenting similar yield as spring rapeseed. Moreover, crambe presents the advantage of being cultivated wherever rapeseed is grown [7].

In Brazil, researches on the culture of crambe began in 1995 in Mato Grosso do Sul Foundation, Mato Grosso do Sul State, to evaluate its behavior in the formation of soil cover [8]. However, with the advent of biofuel production, this oilseed has become quite an interesting option for presenting advantages for its yields, such as earliness, tolerance to drought and frost, low production cost, yields ranging from 1000 to $1500 \mathrm{~kg} \cdot \mathrm{ha}^{-1}$ and increased production of oil compared with crops such as sunflower, oilseed rape, canola and jatropha, among others. Furthermore, crambe does not compete with crops grown for food, making its cultivation feasible for biofuel production [6] [8].

Based on the facts described above, in addition to the lack of specific literature about the effects of saline waters used for irrigation on crambe plants, this work was carried out in order to evaluate the effects on the devel- 
opment and productivity of crambe irrigated with saline waters under greenhouse conditions.

\section{Material and Methods}

The experiment was carried out between September and December 2013 in a greenhouse located in the Academic Unit of Agricultural Engineering at the Federal University of Campina Grande (UFCG), Brazil, situated at $7^{\circ} 12^{\prime} 88^{\prime \prime} \mathrm{S}$ and $35^{\circ} 54^{\prime} 40^{\prime \prime} \mathrm{O}$, with an average altitude of $532 \mathrm{~m}$.

The soil, after being air-dried and sieved, was chemically analyzed by [9] method, and the results are presented in Table 1.

After chemical characterization, the soil was placed in pots with a capacity of $15 \mathrm{dm}^{3}$ and submitted to a basic fertilization following the recommendation of [10] for pots. The dosage $100-300-100 \mathrm{mg} \cdot \mathrm{kg}^{-1}$ of nitrogen, phosphorus and potassium, respectively, was applied by using potassium chloride $(39.1 \% \mathrm{~K})$, single superphosphate $\left(18 \% \mathrm{P}_{2} \mathrm{O}_{5}\right)$, sulfate ammonia $(21 \% \mathrm{~N})$ and urea $(28 \% \mathrm{~N})$.

The volume of water required to achieve the soil at field capacity was determined based on the amount of available water in the soil determined in the laboratory.

The salts $\mathrm{NaCl}$ and $\mathrm{CaCl}_{2}$ were added to the local water supply, in order to obtain waters with different electrical conductivities (EC). The quantity of each salt (Q) was determined by the equation $\mathrm{Q}\left(\mathrm{mg} \cdot \mathrm{L}^{-1}\right)=640 \times$ $\mathrm{ECw}\left(\mathrm{dS} \cdot \mathrm{m}^{-1}\right)$, as [11] state, in which ECw represents the desired value of electrical conductivity of the water. The waters were stored in plastic barrels of 100 liter capacity. Treatments resulted from the combination of two factors: salinity of irrigation water $(\mathrm{ECw})$ in five levels $\left(1.03\right.$-control, $2.5,4.0,5.5$, and $\left.7.0 \mathrm{dS} \cdot \mathrm{m}^{-1}\right)$ and two types of salts $\left(\mathrm{NaCl}\right.$ and the $1: 1$ ratio combination of $\left.\mathrm{NaCl}+\mathrm{CaCl}_{2}\right)$, with three replications, totaling 30 experimental plots.

Crambe seeds, cultivar Brilhante FMS, were provided by the MS Foundation, Office of Maracaju, Mato Grosso do Sul, Brazil, and they were planted in plastic cups on a commercial substrate for the production of seedlings. After 13 days, the seedlings were transplanted into pots and irrigated with water supply for 14 days to ensure its full adaptation to the pots. Then, the irrigation with saline solutions of $\mathrm{NaCl}+\mathrm{NaCl}$ and $\mathrm{CaCl}_{2} \mathrm{was}$ started, which lasted 50 days until harvesting the plants. The irrigation with their respective treatments were conducted twice daily (07:00 a.m. and 04:00 p.m.) applying volumes ranging from $100 \mathrm{ml}$ to $300 \mathrm{ml}$, based on previous work cited by [12].

During the experimental period ( 90 days) the plants were subjected to measurements of plant height, number of leaves and inflorescences and absence or presence of grains on three dates every 15 days. At the end of the experiment the plants were cut, separated in shoots, roots and grains, dried in an oven with forced air circulation at $65^{\circ} \mathrm{C}$ for 72 hours and then weighed on a precision balance of $0.1 \mathrm{~g}$.

At the end of the experimental period, soil samples from each plot were collected for chemical and salinity of soil saturation extract analyzes. Soil and plant data were evaluated using the statistical software SISVAR 5.0 [13].

\section{Results and Discussion}

Statistical analysis was performed separately on the basis of soil analysis: soil complex sorption (Table 2) and salinity (Table 3). Data were subjected to analysis of normality of the residuals by the method of Shapiro-Wilk, being transformed when it was necessary. It was observed a need to transform the data of the soil complex sorption in $1 / \sqrt{x}$ for electrical conductivity (EC) and $\mathrm{Na} ; \sqrt{x}$ for $\mathrm{Ca}, \mathrm{H}+\mathrm{Al}, \mathrm{H}$ and M.O; $1 / x$ for $\mathrm{Mg}$ and $\sqrt{x+1}$ for Al (Table 2). Regarding to soil salinity, it was necessary to transform the data in $1 / \sqrt{x}$ to $\mathrm{EC}$; $1 / x$ to $\mathrm{Na} ; \sqrt{x}$ to $\mathrm{Mg}$ and $\log (\mathrm{x})$ for $\mathrm{Ca}$ and $\mathrm{Cl}$ (Table 3 ).

Table 1. Soil chemical characterization at the beginning of the experiment.

\begin{tabular}{|c|c|c|c|c|c|c|c|c|}
\hline $\mathrm{pH} \mathrm{H} \mathrm{H}_{2} \mathrm{O}$ & E.C. & $\mathrm{Ca}$ & $\mathrm{Mg}$ & $\mathrm{Na}$ & $\mathrm{K}$ & $\mathrm{H}+\mathrm{Al}$ & $\mathrm{P}$ & O.M. \\
\hline$(1: 2.5)$ & $\mathrm{dS} \cdot \mathrm{m}^{-1}$ & & ----- & $\mathrm{nol} \cdot \mathrm{kg}$ & --- & & $\mathrm{mg} \cdot \mathrm{dm}^{-3}$ & $\mathrm{~g} \cdot \mathrm{dm}^{-3}$ \\
\hline 5.41 & 0.10 & 22.6 & 9.4 & 3.4 & 0.3 & 22.3 & 9.3 & 7.7 \\
\hline
\end{tabular}


Table 2. Analysis of variance for the soil complex sorption at the end of the experiment.

\begin{tabular}{cccccccccccc}
\hline Source of variation & D.F. & \multicolumn{7}{c}{ Mean squares } \\
& & $\mathrm{pH}$ & $\mathrm{EC}^{(1)}$ & $\mathrm{Na}^{(1)}$ & $\mathrm{K}$ & $\mathrm{Ca}^{(2)}$ & $\mathrm{Mg}^{(3)}$ & $\mathrm{P}$ & $\mathrm{Al}^{(4)}$ & $\mathrm{O}^{(1)} .^{(2)}$ \\
\hline Salinity levels (N) & 4 & $0.013^{\mathrm{ns}}$ & $0.12^{* *}$ & $0.323^{* *}$ & $0.029^{\mathrm{ns}}$ & $0.23^{* *}$ & $0.04^{\mathrm{ns}}$ & $0.003^{\mathrm{ns}}$ & $0.019^{*}$ & $0.023^{\mathrm{ns}}$ \\
Linear & 1 & $0.011^{\mathrm{ns}}$ & $0.44^{* *}$ & $1.064^{* *}$ & $0.004^{\mathrm{ns}}$ & $0.79^{* *}$ & $0.002^{\mathrm{ns}}$ & $0.066^{\mathrm{ns}}$ & $0.002^{\mathrm{ns}}$ & $0.003^{\mathrm{ns}}$ \\
Quadratic & 1 & $0.027^{\mathrm{ns}}$ & $0.000^{\mathrm{ns}}$ & $0.226^{* *}$ & $0.003^{\mathrm{ns}}$ & $0.03^{\mathrm{ns}}$ & $0.056^{\mathrm{ns}}$ & $0.005^{\mathrm{ns}}$ & $0.057^{*}$ & $0.002^{\mathrm{ns}}$ \\
Deviation & 2 & $0.006^{\mathrm{ns}}$ & $0.012^{\mathrm{ns}}$ & $0.001^{\mathrm{ns}}$ & $0.002^{\mathrm{ns}}$ & $0.05^{\mathrm{ns}}$ & $0.053^{\mathrm{ns}}$ & $0.054^{\mathrm{ns}}$ & $0.016^{\mathrm{ns}}$ & $0.001^{\mathrm{ns}}$ \\
Salts (S) & 1 & $0.100^{* *}$ & $0.034^{*}$ & $0.415^{* *}$ & $0.002^{\mathrm{ns}}$ & $0.01^{\mathrm{ns}}$ & $0.06^{\mathrm{ns}}$ & $0.012^{* *}$ & $0.008^{\mathrm{ns}}$ & $0.029^{*}$ \\
N $\times$ S & 4 & $0.008^{\mathrm{ns}}$ & $0.006^{\mathrm{ns}}$ & $0.106^{* *}$ & $0.008^{\mathrm{ns}}$ & $0.01^{\mathrm{ns}}$ & $0.04^{\mathrm{ns}}$ & $0.001^{* *}$ & $0.008^{\mathrm{ns}}$ & $0.041^{\mathrm{ns}}$ \\
Treatment & 9 & $0.02^{\mathrm{ns}}$ & $0.52^{* *}$ & $0.23^{* *}$ & $0.001^{\mathrm{ns}}$ & $0.10^{* *}$ & $0.04^{\mathrm{ns}}$ & $0.002^{* *}$ & $0.009^{\mathrm{ns}}$ & $0.006^{\mathrm{ns}}$ \\
Error & 20 & 0.009 & 0.004 & 0.011 & 0.0024 & 0.02 & 0.05 & 0.002 & 0.065 & 0.006 \\
CV (\%) & & 1.99 & 8.23 & 10.89 & 12.91 & 9.49 & 29.41 & 0.39 & 7.01 & 11.08 \\
Mean & & 5.00 & 0.827 & 0.983 & 0.385 & 1.62 & 0.76 & 3.846 & 1.15 & 0.737 \\
\hline
\end{tabular}

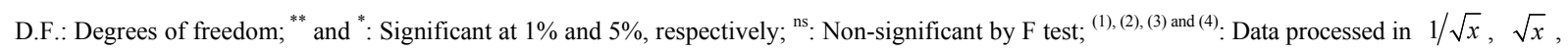
$1 / x$ and $\sqrt{x+1}$, respectively.

Table 3. Analysis of variance for the salinity of soil saturation extract at the end of experiment.

\begin{tabular}{|c|c|c|c|c|c|c|c|c|c|}
\hline \multirow[t]{2}{*}{ Source of variation } & \multirow[t]{2}{*}{ D.F. } & \multicolumn{8}{|c|}{ Mean squares } \\
\hline & & $\mathrm{pH}$ & $\mathrm{EC}^{(1)}$ & $\mathrm{Na}^{(2)}$ & K & $\mathrm{Ca}^{(4)}$ & $\mathrm{Mg}^{(3)}$ & $\mathrm{HCO}_{3}$ & $\mathrm{Cl}^{(4)}$ \\
\hline Salinity levels (N) & 4 & $0.02 \mathrm{~ns}$ & $0.03^{* *}$ & $0.06^{* *}$ & $5.12^{* *}$ & $0.14^{* *}$ & $3.35^{* *}$ & $0.08 \mathrm{~ns}$ & $0.26^{* *}$ \\
\hline Linear & 1 & $0.06^{*}$ & $0.04^{* *}$ & $0.09^{* *}$ & $19.62^{* *}$ & $0.48^{* *}$ & $3.35^{* *}$ & $0.29 \mathrm{~ns}$ & $0.825^{* *}$ \\
\hline Quadratic & 1 & $0.04 \mathrm{~ns}$ & $0.01 \mathrm{~ns}$ & $0.05^{* *}$ & $0.15 \mathrm{~ns}$ & $0.01 \mathrm{~ns}$ & $0.19 \mathrm{~ns}$ & $0.02 \mathrm{~ns}$ & $0.01 \mathrm{~ns}$ \\
\hline Deviation & 2 & $0.04 \mathrm{~ns}$ & $0.03^{* *}$ & $0.05 \mathrm{~ns}$ & $0.35 \mathrm{~ns}$ & $0.04 \mathrm{~ns}$ & $0.38 \mathrm{~ns}$ & $0.02 \mathrm{~ns}$ & $0.04^{*}$ \\
\hline Salts (S) & 1 & $0.16^{* *}$ & $0.02^{*}$ & $0.03^{* *}$ & $0.04 \mathrm{~ns}$ & $0.02 \mathrm{~ns}$ & $0.19 \mathrm{~ns}$ & $0.04 \mathrm{~ns}$ & $0.05^{*}$ \\
\hline $\mathrm{N} \times \mathrm{S}$ & 4 & $0.07 \mathrm{~ns}$ & $0.05 \mathrm{~ns}$ & $0.03^{* *}$ & $0.43 \mathrm{~ns}$ & $0.01 \mathrm{~ns}$ & $0.38 \mathrm{~ns}$ & $0.48^{*}$ & $0.09 \mathrm{~ns}$ \\
\hline Treatment & 9 & $0.03^{*}$ & $0.06^{* *}$ & $0.05^{* *}$ & $2.46^{*}$ & $0.07^{* *}$ & $1.68^{* *}$ & $0.26 \mathrm{~ns}$ & $0.12^{* *}$ \\
\hline Error & 20 & 0.01 & 0.05 & 0.02 & 0.83 & 0.02 & 0.34 & 0.14 & 0.07 \\
\hline CV $(\%)$ & & 2.41 & 6.74 & 15.93 & 15.14 & 7.86 & 9.67 & 22.84 & 4.10 \\
\hline Mean & & 4.59 & 0.28 & 0.028 & 6.093 & 1.735 & 6.07 & 1.676 & 2.05 \\
\hline
\end{tabular}

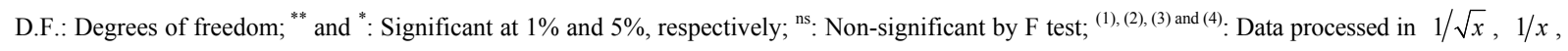
$\sqrt{x}$ and $\log (\mathrm{x})$, respectively.

The effects of salinity levels on soil complex sorption at the end of the experiment were significant to electric conductivity (EC), sodium ( $\mathrm{Na}$ ), calcium $(\mathrm{Ca})$, and aluminum $(\mathrm{Al})$. In addition, the types of salts were significant for $\mathrm{pH}, \mathrm{EC}, \mathrm{Na}$, phosphorus $(\mathrm{P})$, and organic matter (O.M.). The interaction between salinity levels and types of salts was significant for $\mathrm{Na}$ and $\mathrm{P}$ (Table 2).

The treatments used in this experiment also presented significant effects on the soil saturation extract at the end of the experiment (Table 3). Salinity levels were significant for E.C., $\mathrm{Na}, \mathrm{K}, \mathrm{Ca}, \mathrm{Cl}$, while the types of salts were significant for $\mathrm{pH}$, E.C., $\mathrm{Na}$ and $\mathrm{Cl}$. The interaction between salinity levels and types of salts was significant for $\mathrm{Na}$ and $\mathrm{HCO}_{3}$.

Subsequently, the soil data were subjected to analysis of variance and to the analysis of the splitting factors, 
when it was necessary. For significant effects of the factor "salts", the Tukey test was performed for comparison of means at $5 \%$ probability, while for the significant effects of salinity levels it was applied the regression analysis (Table 4 and Table 5).

For the soil complex (Table 4), the values of $\mathrm{pH}$ were higher for the combination of $\mathrm{NaCl}+\mathrm{CaCl}_{2}$ in the solutions at 4.0 and $5.5 \mathrm{dS} \cdot \mathrm{m}^{-1}$ salinity levels. The $\mathrm{Na}$ content was higher for $\mathrm{NaCl}$ solutions at those same salinity levels $\left(4.0\right.$ and $\left.5.5 \mathrm{dS} \cdot \mathrm{m}^{-1}\right)$. Phosphorus presented higher values for the combination of $\mathrm{NaCl}+\mathrm{CaCl}_{2}$ in the solutions for all the salinity levels, except for the $7.0 \mathrm{dS} \cdot \mathrm{m}^{-1}$.

For soil salinity (Table 5), the highest increase observed for the adopted salinity levels of this study can be observed for $\mathrm{Na}$ content, where the $\mathrm{NaCl}$ solution presented this increase for $2.5,4.0$ and $5.5 \mathrm{dS} \cdot \mathrm{m}^{-1}$ salinity levels. Electrical conductivity presented higher value for $\mathrm{NaCl}$ solution at $5.5 \mathrm{dS} \cdot \mathrm{m}^{-1}$.

Plant data also were subjected to analysis of normality of the residuals by the method of Shapiro-Wilk and it was observed a need to transform the data in $\sqrt{Y+0.5}$ (Table 6). As it can be observed, salt types do not affected plant parameters (Table 6), namely dry weight of shoots and roots, number of inflorescences, dry weight of grains and root-shoot ratio. However, the salinity levels presented significant effects on the all parameters: as the salt dose increased, plant dry-matter (shoots and roots), inflorescences and grain weight decreased with the salinity levels, following a linear trend (Figure 1).

Plants adversely affected by salinity grow more slowly and are, therefore, stunted. Leaves are smaller, but may be thicker than those of normal plants and chloride increases the elongation of the palisade cells, causing increased succulence. The leaves of salt-affected plants are often darker green than those of normal plants, but in crucifers thicker layers of surface wax cause a bluish-green cast. Stunting of fruits as well as leaves and stems occurs. Salt-affected plants may show no distinctive symptoms, and only comparison with normal plants reveals

Table 4. Comparison of means of soil complex sorption by Tukey test for salt type.

\begin{tabular}{|c|c|c|c|c|c|c|}
\hline \multirow[t]{2}{*}{ Salt } & \multicolumn{5}{|c|}{ Salinity levels $\left(\mathrm{dS} \cdot \mathrm{m}^{-1}\right)$} & \multirow[t]{2}{*}{ Equation } \\
\hline & 1.03 & 2.5 & 4.0 & 5.5 & 7.0 & \\
\hline & & & $\mathrm{pH}$ & & & \\
\hline $\mathrm{NaCl}$ & $5.04 \mathrm{a}$ & $4.92 \mathrm{a}$ & $4.90 \mathrm{~b}$ & $4.84 b$ & $5.00 \mathrm{a}$ & $\mathrm{Y}=0.01 \mathrm{x}^{2}-0.14+5.17 \mathrm{R}^{2}=0.8704^{*}$ \\
\hline \multirow[t]{2}{*}{$\mathrm{NaCl}+\mathrm{CaCl}_{2}$} & $5.09 \mathrm{a}$ & $5.04 \mathrm{a}$ & $5.09 \mathrm{a}$ & $5.03 \mathrm{a}$ & $5.03 \mathrm{a}$ & $\mathrm{Y}=5.06^{\mathrm{ns}}$ \\
\hline & & & $\mathrm{EC}$ & & & \\
\hline $\mathrm{NaCl}$ & $1.02 \mathrm{a}$ & $0.87 \mathrm{a}$ & $0.88 \mathrm{a}$ & $0.85 \mathrm{a}$ & $0.67 \mathrm{a}$ & $\mathrm{Y}=-0.04 \mathrm{x}+1.05 \mathrm{R}^{2}=0.8359^{* *}$ \\
\hline \multirow[t]{2}{*}{$\mathrm{NaCl}+\mathrm{CaCl}_{2}$} & $1.00 \mathrm{a}$ & $0.85 \mathrm{a}$ & $0.83 \mathrm{a}$ & $0.66 \mathrm{~b}$ & $0.61 \mathrm{a}$ & $\mathrm{Y}=-0.06 \mathrm{x}+1.05 \mathrm{R}^{2}=0.9594^{* *}$ \\
\hline & & & $\mathrm{Na}$ & & & \\
\hline $\mathrm{NaCl}$ & $1.16 \mathrm{a}$ & $1.23 \mathrm{a}$ & $1.37 \mathrm{a}$ & $1.13 \mathrm{a}$ & $0.60 \mathrm{a}$ & $Y=-0.05 x^{2}+0.32 x+0.83 R^{2}=0.9554^{* *}$ \\
\hline \multirow[t]{2}{*}{$\mathrm{NaCl}+\mathrm{CaCl}_{2}$} & $1.12 \mathrm{a}$ & $1.12 \mathrm{a}$ & $0.78 b$ & $0.68 b$ & $0.61 \mathrm{a}$ & $\mathrm{Y}=-0.09 \mathrm{x}+1.25 \mathrm{R}^{2}=0.8987^{* *}$ \\
\hline & & & $\mathrm{Ca}$ & & & \\
\hline $\mathrm{NaCl}$ & $1.32 \mathrm{a}$ & $1.61 \mathrm{a}$ & $1.59 \mathrm{a}$ & $1.68 \mathrm{a}$ & $1.78 \mathrm{a}$ & $\mathrm{Y}=0.06 \mathrm{x}+1.33 \mathrm{R}^{2}=0.8282^{* *}$ \\
\hline \multirow[t]{2}{*}{$\mathrm{NaCl}+\mathrm{CaCl}_{2}$} & $1.34 \mathrm{a}$ & $1.62 \mathrm{a}$ & $1.53 \mathrm{a}$ & $1.78 \mathrm{a}$ & $1.93 \mathrm{a}$ & $\mathrm{Y}=0.08 \mathrm{x}+1.28 \mathrm{R}^{2}=0.8624^{* *}$ \\
\hline & & & $\mathrm{P}$ & & & \\
\hline $\mathrm{NaCl}$ & $3.81 \mathrm{~b}$ & $3.83 b$ & $3.80 \mathrm{~b}$ & $3.83 b$ & $3.84 \mathrm{a}$ & $\mathrm{Y}=0.004 \mathrm{x}+3.807 \mathrm{R}^{2}=0.4756^{*}$ \\
\hline \multirow[t]{2}{*}{$\mathrm{NaCl}+\mathrm{CaCl}_{2}$} & $3.89 \mathrm{a}$ & $3.86 a$ & $3.87 \mathrm{a}$ & $3.87 \mathrm{a}$ & $3.83 \mathrm{a}$ & $Y=-0.006 x+3.89 R^{2}=0.6047^{* *}$ \\
\hline & & & $\mathrm{H}+\mathrm{Al}$ & & & \\
\hline $\mathrm{NaCl}$ & $1.11 \mathrm{~b}$ & $1.04 \mathrm{a}$ & $0.95 b$ & $1.01 \mathrm{~b}$ & $1.15 b$ & $\mathrm{Y}=0.01 \mathrm{x}^{2}-0.14 \mathrm{x}+1.25 \mathrm{R}^{2}=0.9238^{*}$ \\
\hline $\mathrm{NaCl}+\mathrm{CaCl}_{2}$ & $1.30 \mathrm{a}$ & $1.23 \mathrm{a}$ & $1.18 \mathrm{a}$ & $1.35 \mathrm{a}$ & $1.37 \mathrm{a}$ & $\mathrm{Y}=1.29^{\mathrm{ns}}$ \\
\hline
\end{tabular}

Means followed with the same letter within the same column do not differ statistically. 
Table 5. Comparison of means of soil salinity by Tukey test for salt type.

\begin{tabular}{|c|c|c|c|c|c|c|}
\hline \multirow[t]{2}{*}{ Salt } & \multicolumn{5}{|c|}{ Salinity levels $\mathrm{dS} \cdot \mathrm{m}^{-1}$} & \multirow[t]{2}{*}{ Equation } \\
\hline & 1.03 & 2.5 & 4.0 & 5.5 & 7.0 & \\
\hline & \multicolumn{5}{|c|}{$\mathrm{EC}$} & \\
\hline $\mathrm{NaCl}$ & $0.34 \mathrm{a}$ & $0.29 \mathrm{a}$ & $0.29 \mathrm{a}$ & $0.28 \mathrm{a}$ & $0.22 \mathrm{a}$ & $Y=-0.016 x+0.353 R^{2}=0.83^{* *}$ \\
\hline $\mathrm{NaCl}+\mathrm{CaCl}_{2}$ & $0.34 \mathrm{a}$ & $0.27 \mathrm{a}$ & $0.27 \mathrm{a}$ & $0.23 \mathrm{~b}$ & $0.21 \mathrm{a}$ & $\mathrm{Y}=-0.020 \mathrm{x}+0.352 \mathrm{R}^{2}=0.92^{* *}$ \\
\hline \multicolumn{7}{|c|}{$\mathrm{Na}$} \\
\hline $\mathrm{NaCl}$ & $0.035 \mathrm{a}$ & $0.037 \mathrm{a}$ & $0.050 \mathrm{a}$ & $0.037 \mathrm{a}$ & $0.012 \mathrm{a}$ & $\mathrm{Y}=-0.002 \mathrm{x}^{2}+0.017 \mathrm{x}+0.017 \mathrm{R}^{2}=0.88^{* *}$ \\
\hline $\mathrm{NaCl}+\mathrm{CaCl}_{2}$ & $0.037 \mathrm{a}$ & $0.029 b$ & $0.019 \mathrm{~b}$ & $0.014 \mathrm{~b}$ & $0.011 \mathrm{a}$ & $Y=-0.004 x+0.040 R^{2}=0.96^{* *}$ \\
\hline \multicolumn{7}{|c|}{ K } \\
\hline $\mathrm{NaCl}$ & $5.04 \mathrm{a}$ & $5.45 \mathrm{a}$ & $6.16 \mathrm{a}$ & $6.33 \mathrm{a}$ & $7.10 \mathrm{a}$ & $\mathrm{Y}=0.33 \mathrm{x}+4.68 \mathrm{R}^{2}=0.97^{* *}$ \\
\hline $\mathrm{NaCl}+\mathrm{CaCl}_{2}$ & $4.63 \mathrm{a}$ & $5.86 \mathrm{a}$ & $5.39 \mathrm{a}$ & $6.57 \mathrm{a}$ & $7.51 \mathrm{a}$ & $\mathrm{Y}=0.43 \mathrm{x}+4.26 \mathrm{R}^{2}=0.85^{* *}$ \\
\hline \multicolumn{7}{|c|}{$\mathrm{Ca}$} \\
\hline $\mathrm{NaCl}$ & $1.44 \mathrm{a}$ & $1.71 \mathrm{a}$ & $1.73 \mathrm{a}$ & $1.76 \mathrm{a}$ & $1.86 \mathrm{a}$ & $\mathrm{Y}=0.06 \mathrm{x}+1.462 \mathrm{R}^{2}=0.81^{* *}$ \\
\hline $\mathrm{NaCl}+\mathrm{CaCl}_{2}$ & $1.57 \mathrm{a}$ & $1.76 \mathrm{a}$ & $1.63 \mathrm{a}$ & $1.80 \mathrm{a}$ & $2.00 \mathrm{a}$ & $\mathrm{Y}=0.06 \mathrm{x}+1.51 \mathrm{R}^{2}=0.72^{* *}$ \\
\hline \multicolumn{7}{|c|}{$\mathrm{Mg}$} \\
\hline $\mathrm{NaCl}$ & $5.39 \mathrm{a}$ & $6.21 \mathrm{a}$ & $5.84 \mathrm{a}$ & $6.54 \mathrm{a}$ & $6.76 \mathrm{a}$ & $\mathrm{Y}=0.20 \mathrm{x}+5.32 \mathrm{R}^{2}=0.78^{* *}$ \\
\hline $\mathrm{NaCl}+\mathrm{CaCl}_{2}$ & $4.60 \mathrm{a}$ & $5.66 \mathrm{a}$ & $5.99 \mathrm{a}$ & $6.46 \mathrm{a}$ & $7.22 \mathrm{a}$ & $\mathrm{Y}=0.40 \mathrm{x}+4.37 \mathrm{R}^{2}=0.96^{* *}$ \\
\hline \multicolumn{7}{|c|}{$\mathrm{HCO}_{3}$} \\
\hline $\mathrm{NaCl}$ & $2.22 \mathrm{a}$ & $1.92 \mathrm{a}$ & $1.51 \mathrm{a}$ & $1.38 \mathrm{a}$ & $1.50 \mathrm{a}$ & $Y=-0.13 x+2.24 R^{2}=0.79^{*}$ \\
\hline $\mathrm{NaCl}+\mathrm{CaCl}_{2}$ & $1.36 \mathrm{~b}$ & $1.55 \mathrm{a}$ & $1.80 \mathrm{a}$ & $1.98 \mathrm{a}$ & $1.44 \mathrm{a}$ & $\mathrm{Y}=1.63^{\mathrm{ns}}$ \\
\hline \multicolumn{7}{|c|}{$\mathrm{Cl}$} \\
\hline $\mathrm{NaCl}$ & $1.79 \mathrm{a}$ & $1.99 \mathrm{a}$ & $1.95 \mathrm{a}$ & $2.02 \mathrm{~b}$ & $2.28 \mathrm{a}$ & $\mathrm{Y}=0.06 \mathrm{x}+1.73 \mathrm{R}^{2}=0.81^{* *}$ \\
\hline $\mathrm{NaCl}+\mathrm{CaCl}_{2}$ & $1.78 \mathrm{a}$ & $2.04 \mathrm{a}$ & $2.07 \mathrm{a}$ & $2.21 \mathrm{a}$ & $2.36 \mathrm{a}$ & $\mathrm{Y}=0.08 \mathrm{x}+1.73 \mathrm{R}^{2}=0.94^{* *}$ \\
\hline
\end{tabular}

Means followed with the same letter within the same column do not differ statistically.

Table 6. Analysis of variance for the parameters of plants at the end of experiment.

\begin{tabular}{ccccccc}
\hline Source of variation & D.F. & \multicolumn{5}{c}{ Mean squares } \\
\hline & & Shoots & Roots & Inflorescence & Grain & SRR $^{(2)}$ \\
\hline Salinity levels (N) & 4 & $70.03^{*}$ & $0.24 \mathrm{~ns}$ & $50.045^{* *}$ & $3.9624^{* *}$ & $0.00073 \mathrm{~ns}^{* *}$ \\
Linear & 1 & $253.95^{* *}$ & $0.725^{*}$ & $182.583^{* *}$ & $14.837^{* *}$ & $0.0022^{*}$ \\
Quadratic & 1 & $0.13 \mathrm{~ns}$ & $0.043 \mathrm{~ns}$ & $7.883 \mathrm{~ns}$ & $0.009 \mathrm{~ns}$ & $0.0002 \mathrm{~ns}$ \\
Deviation & 2 & $7.68 \mathrm{~ns}$ & $0.085 \mathrm{~ns}$ & 1.676 & $0.198 \mathrm{~ns}$ & $0.0001 \mathrm{~ns}$ \\
Salts (S) & 1 & $9.50 \mathrm{~ns}$ & $0.00 \mathrm{~ns}$ & $1.938 \mathrm{~ns}$ & $0.0232 \mathrm{~ns}$ & $0.00100 \mathrm{~ns}$ \\
N $\times$ S & 4 & $14.20 \mathrm{~ns}$ & $0.21 \mathrm{~ns}$ & $0.153 \mathrm{~ns}$ & $0.2420 \mathrm{~ns}$ & $0.00090 \mathrm{~ns}$ \\
Error & 19 & 16.43 & 0.09 & 2.770 & $0.6166 \mathrm{~ns}$ & 0.00034 \\
CV (\%) & & 42.25 & 45.44 & 34.44 & 76.14 & 25.0 \\
Mean & & 9.59 & 0.6906 & 4.8321 & 1.0313 & 0.074 \\
\hline
\end{tabular}

${ }^{(1)}$ Data transformed in $\sqrt{Y+0.5} ;{ }^{(2)}$ Shoot-root ratio. 


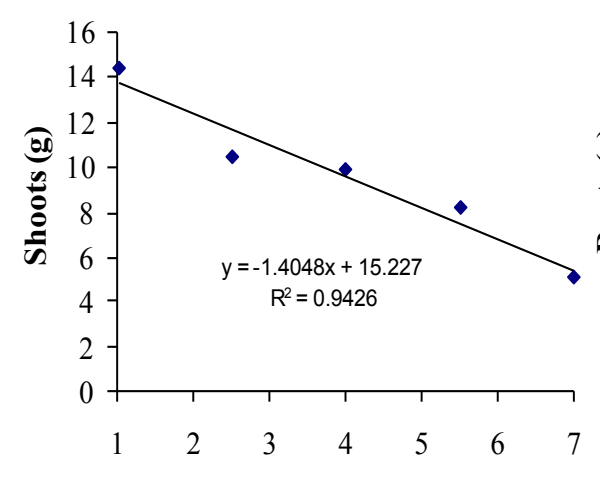

Salinity levels $\left(\mathrm{dS} \mathbf{m}^{-1}\right)$

(a)

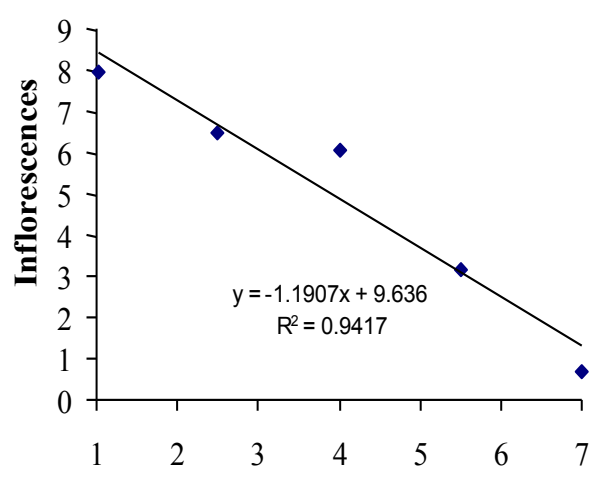

Salinity levels (dS m$\left.{ }^{-1}\right)$

(c)

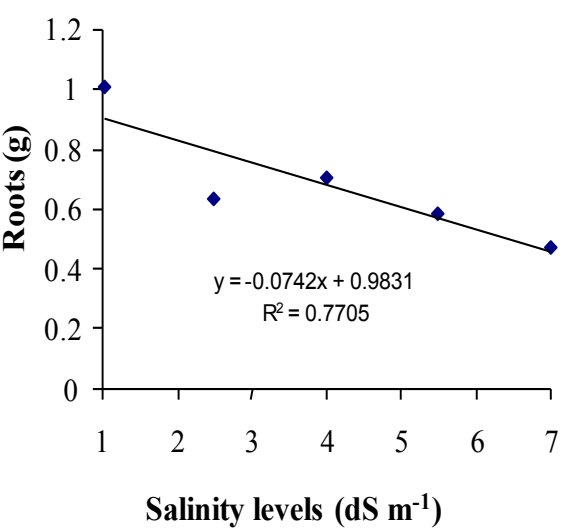

(b)

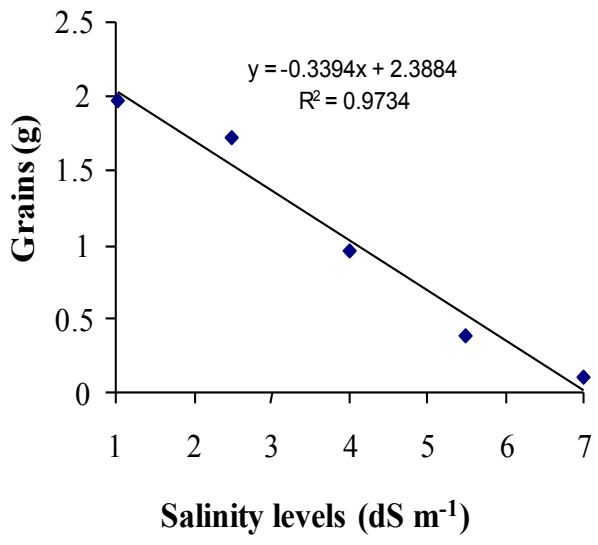

(d)

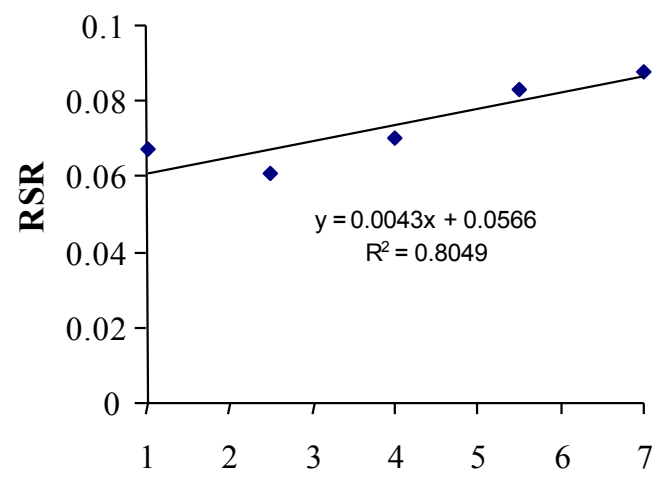

Salinity levels (dS m-1)

(e)

Figure 1. Effects of salinity levels in the shoots (a), roots (b), inflorescences (c), grains (d), and in the shoot-root ratio (e) of plants of crambe at the end of the experiment.

the extent of salt inhibition [2]. Those symptoms could be observed in crambe plants during the experimental period, corroborating with the general description on [2] and also with [14], who studied the development of crambe plants irrigated with saline waters.

The changes in metabolism induced by salinity are consequences of several physiological responses of the plant, such as changes in ionic balance, stomatal behavior and photosynthetic efficiency. The salt concentration increases in the cytoplasm and inhibits the enzyme activity of several metabolic routes and alternatively by the compartmentalization in the vacuole, the salts can be transported to the cell wall resulting in turn in dehydration 
of the cell. The high concentration of sodium or other cations in soil solution interfere with the physical condition of the soil or the availability of other elements, indirectly affecting plant development [15].

The shoot-root ratio increased with the salinity levels (Figure 1(e)), indicating that crambe plants produced a higher proportion of shoots compared to the roots even under the presence of salts in soil, which means that roots competed effectively for soil nutrients and allowed a better development of plants under salinity conditions.

It is worth evaluating the development of crambe under saline conditions in salinity levels up to $7.0 \mathrm{dS} \cdot \mathrm{m}^{-1}$, taking into account the adoption of special measures to control salinity, as leaching of salts in the soil, as [4] studied. These authors concluded that the two-year greenhouse experiments show that irrigation of crambe with moderate salinities (ranging from 3.0 to $9.0 \mathrm{dS} \cdot \mathrm{m}^{-1}$ but adopting salt leaching from soil) is feasible and classify this crop in the moderately sensitive salt tolerance category.

\section{Conclusion}

Salinity levels of the solutions used for irrigation in this study affected the growth of plants and grain yield of crambe. Regarding the type of salts, a higher concentration of $\mathrm{Na}$ was observed for $\mathrm{NaCl}$ solutions at 2.5, 4.0 and $5.5 \mathrm{dS} \cdot \mathrm{m}^{-1}$ salinity levels. It is worth evaluating crambe growth under salinity levels ranging up to 5.0 $\mathrm{dS} \cdot \mathrm{m}^{-1}$, but adopting salt leaching from soil.

\section{References}

[1] Liu, Y., Li, X., Ma, J. and Ling, X. (2007) Seed Mass and Shape, Germination and Plant Abundance in a Desertified Grassland in Northeastern Inner Mongolia, China. Journal of Arid Environments, 69, 198-211. http://dx.doi.org/10.1016/j.jaridenv.2006.09.012

[2] Bernstein, L. (1975) Effects of Salinity and Sodicity on Plant Growth. Annual Review of Phytopathology, 13, 295-312. http://dx.doi.org/10.1146/annurev.py.13.090175.001455

[3] Turan, M. and Aydin, A. (2005) Effects of Different Salt Sources on Growth, Inorganic Ions and Proline Accumulation in Corn (Zea mays L.). European Journal of Horticulture Science, 70, 149-155.

[4] Ionov, M., Yuldasheva, N., Ulchenko, N., Glushenkova, A.I. and Heuer, B. (2013) Growth, Development and Yield of Crambe Abyssinica under Saline Irrigation in the Greenhouse. Journal of Agronomy and Crop Science, 199, 331-339. http://dx.doi.org/10.1111/jac.12027

[5] Oplinger, E.S., Oelke, E.A., Kaminski, A.R., Putnam, D.H., Teynor, T.M., Doll, J.D., Kelling, K.A., Durgan, B. R. and Noetzel, D.M. (1991) Crambe: Alternative Field Crops Manual. University of Wisconsin and University of Minnesota, St. Paul.

[6] Jasper, P.A., Biaggioni, M.A.M., Silva, P.R., Seki, A.A.S. and Bueno, C.O. (2010) Análise Energética da Cultura do Crambe (Crambe abyssinica Hochst) produzida em Plantio Direto. Engenharia Agrícola, 30, 395-403.

[7] Carlsson, A.S. (2006) Production of Wax Esters in Crambe. EPOBIO: Realising the Economic Potential of Sustainable Resources-Bioproducts from Non-Food Crops. CNAP: University of York. http://www.agronavigator.cz/userfiles/File/Agronavigator/Kvasnickova/Epobio_waxesters.pdf

[8] Baez, O. (2007) Crambe a grande aposta das pesquisas em Mato Grosso do Sul. Pantanal News. http://www.biodiselbr.com/noticias/em-foco/crambe-grande-aposta-pesquisas-mato-grosso-sul.htm

[9] Empresa Brasileira de Pesquisa Agropecuária. Ministério da Agricultura e do Abastecimento (EMBRAPA) (1997) Manual de métodos de análises de solo. 2nd Edition, Embrapa CNPS, Rio de Janeiro, 212 p.

[10] Novais, R.F., Neves, J.C.L. and Barros, N.F. (1991) Ensaio em ambiente controlado. In: Oliveira, A.J., Garrido, W.E., Araújo, J.D. and Lourenço, S., Coord., Métodos de pesquisa em fertilidade do solo, Cap. 2, EMBRAPA, Brasília, 189-198.

[11] Rhoades, J.D., Kandiah, A.M. and Marshali, A.M. (2000) Uso de águas salinas para produção agrícola. Universidade Federal da Paraíba, Campina Grande, 117 p.

[12] Nobre, R.G., Fernandes, P.D., Gheyi, H.R., Santos, F.J.S., Bezerra, I.L. and Gurgel, M.T. (2003) Germinação e formação de mudas enxertadas de gravioleira sob estresse salino. Pesquisa Agropecuária Brasileira, 38, 1365-1371. http://dx.doi.org/10.1590/S0100-204X2003001200002

[13] Ferreira, D.F. (2011) Sisvar: A Computer Statistical Analysis System. Ciência e Agrotecnologia (UFLA), 35, 10391042.

[14] Yuldasheva, N.K., Chernenko, T.V, Skosyreva, O.V. and Glushenkova, A.I. (2011) Influence of Irrigation-Water Sa- 
linity on Lipids of Crambe abyssinica Seeds. Chemistry of Natural Compounds, 46, 862-865. http://dx.doi.org/10.1007/s10600-011-9769-8

[15] Santos, V.L.M., Calil, A.C., Ruiz, H.A., Alvarenga, E.M. and Santos, C.M. (1992) Efeito do estresse salino e hídrico na germinação e vigor de sementes de soja. Revista Brasileira de Sementes, 14, 189-194. 